DOI : $10.14746 / \mathrm{pp} .2015 .20 .1 .4$

Radosław MARZĘCKI

Kraków

\title{
Depolityzacja jako element stylu życia młodzieży
}

\begin{abstract}
Streszczenie: W naukowej refleksji nad postawami młodych ludzi w sferze politycznej czy publicznej rzadko zwraca się uwagę na konsekwencje zmiany młodzieżowego stylu życia. Tymczasem nowy model postępowania w życiu codziennym w gruncie rzeczy pomija politykę i wszystko co polityczne, jako obiekty mało atrakcyjne. W hierarchiach wartości młodzi ludzie przyznają polityce marginalne miejsce. Nie stanowi ona również wypełnienia czasu wolnego, który młode pokolenie woli poświęcić rozrywce. Rzadko bywa ona przedmiotem konwersacji z najbliższym otoczeniem - rodziną czy przyjaciółmi. Na podstawie zaprezentowanych danych autor stara się uargumentować tezę, że znaczna część młodego pokolenia mieszkańców Unii Europejskiej (ze szczególnym uwzględnieniem młodych Polaków) preferuje „zdepolityzowany” styl życia.
\end{abstract}

Słowa kluczowe: młodzież, styl życia, depolityzacja, kultura polityczna, partycypacja

\section{Wprowadzenie}

K rytycyzm, który często towarzyszy wielu potocznym diagnozom jakości młodzieżowego obywatelstwa nierzadko bazuje na przekonaniu, że głównym czynnikiem kształtującym postawy młodego obywatela w sferze publicznej czy politycznej jest wąsko rozumiany brak zainteresowania, wiedzy i chęci do jej zdobywania. Pomija się przy tym fakt, że owe postawy (większa bierność) wynikać mogą z silnie utrwalonych norm, reguł, wartości i wzorów zachowań zwanych kulturą polityczną (Almond, Verba, 1995; Wiatr, 2009, s. 189-196). W tym sensie to ona determinuje ludzkie wybory: być aktywnym czy też pozostać w sferze prywatnej, nie angażować się w życie państwa lub społeczeństwa. To, co obserwowalne z zewnątrz - a więc zachowania - stanowią bowiem jedynie ekspresję struktury naszej świadomości, ukształtowanej w długim i ciągłym procesie socjalizacji (także tej politycznej), kiedy przyjmujemy za własne określone hierarchie wartości, definiujemy potrzeby, uświadamiamy sobie swoje interesy (Sztompka, 2005, s. 220-221). Krytycyzm zatem wynikać może z przypuszczenia, że młodzi ludzie mogliby z łatwością zmienić swoje zachowania, gdyby jedynie chcieli. Jednakże znajomość praktyki życia społecznego podpowiada, że wiele z owych pesymistycznych wizji jest częścią opisu rzeczywistego stylu życia młodego pokolenia, w którym polityka zajmuje marginalne miejsce. Jego zmiana jest możliwa, ale wielość czynników formujących style życia, jak również specyfika późnej nowoczesności powodują, że kontrola tej zmiany staje się niezwykle trudna.

\section{Dominujące postawy w polu polityki}

W naukowym opisie problemu młodzieżowej partycypacji politycznej co prawda zwraca się uwagę na trwalsze postawy, posługując się takimi określeniami jak: ,wyzby- 
cie się praw obywatelskich” (Adsett, 2003), upadek kapitału społecznego, „depolityzacja” młodych ludzi (Vrcan, 2002), „słabość społeczeństwa” (Tivadar, Polona, 2002), „marginalizacja” (Svynarenko, 2001) czy „,anomia” (Adnanes, 2000). Rzadziej jednak dostrzega się, że są one przejawem i efektem zmiany stylu życia ludzi młodych. Ten nowy model postępowania w życiu codziennym w gruncie rzeczy pomija politykę i wszystko, co polityczne jako obiekty mało atrakcyjne. W hierarchiach wartości sama polityka i działalność związana z rządzeniem (także szeroko rozumianym) zajmuje odległe miejsce. Nie stanowi też wypełnienia czasu wolnego, który młodzi ludzie wolą poświęcić rozrywce. Rzadko bywa kontekstem różnych aktywności w czasie wolnym od pracy (np. tematem rozmów). Wymienione tutaj zjawiska nie są czymś szczególnym dla młodych ludzi, a raczej opisują uniwersalne cechy wielu społeczeństw. Paul Howe podkreśla, że - chociażby absencja wyborcza - po pierwsze nie jest zjawiskiem ograniczonym jedynie do najmłodszych obywateli, po drugie - nie jest zjawiskiem nowym (Howe, 2006, s. 138). W rzeczywistości, wiele negatywistycznych konkluzji, które formułujemy pod adresem młodego pokolenia, moglibyśmy zastosować - jedynie w nieco łagodniejszej formie - kreśląc społeczno-polityczny portret całego społeczeństwa. Argumentem na rzecz takiej tezy mogą być dane zaprezentowane na wykresie 1. Ilustruje on poziom zainteresowania polityką w krajach objętych badaniem World Values Survey w okresie 1981-2007 ${ }^{1}$. Okazuje się, że odsetek ,niezainteresowanych” w grupie wiekowej

\section{Wykres 1. Poziom zainteresowania polityką w krajach objętych badaniem WVS w okresie 1981-2007}

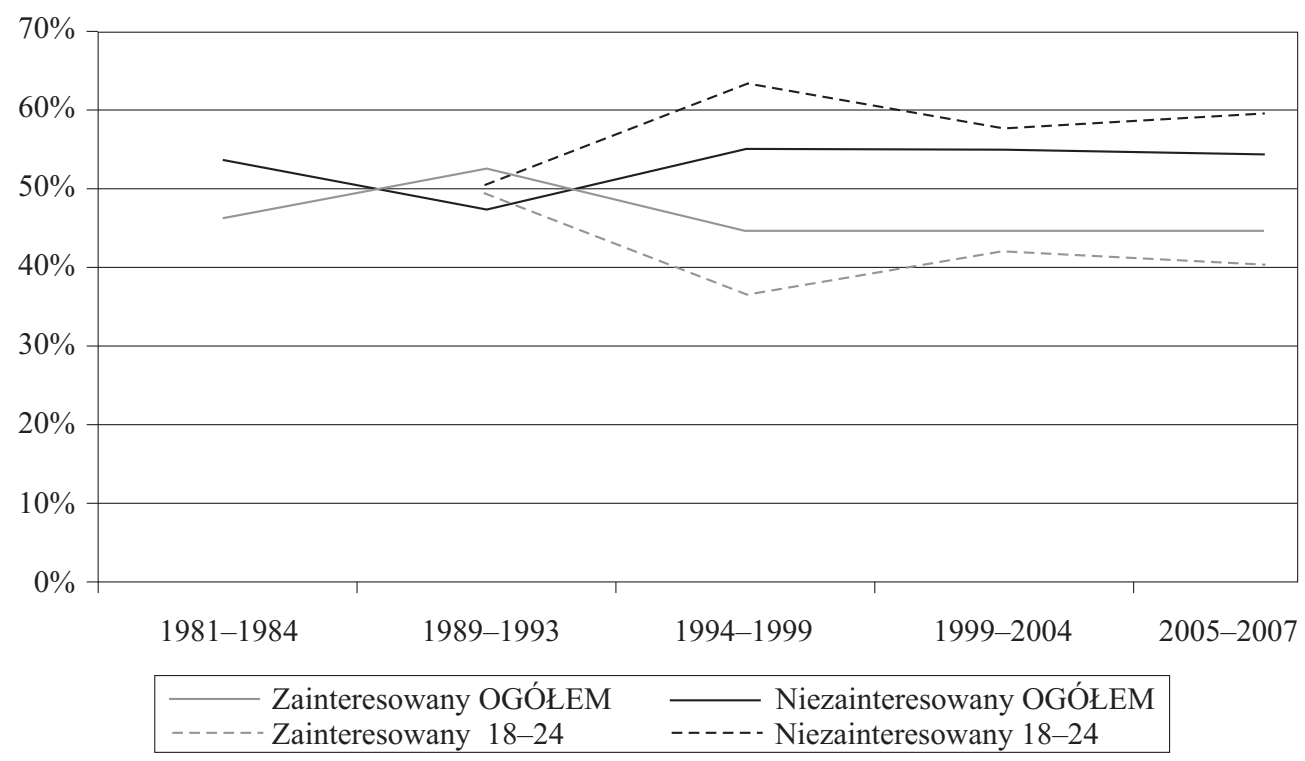

Źródło: World Values Survey 1981-2008.

${ }^{1}$ Światowy Sondaż Wartości jest badaniem, podczas którego diagnozuje się zmiany w zakresie społecznej aksjologii i ich wpływ na życie społeczne i polityczne. Od 1981 roku przeprowadzono 6 edycji Światowego Sondażu Wartości. Ostatnia edycja (2010-2014) objęła 75 państw świata. 
18-24 lata zawsze był wyższy niż wśród ogółu badanych. I podobnie, jeśli chodzi o poziom zainteresowania polityką. Wśród respondentów natomiast wyraźnie przeważają osoby, których polityka nie interesuje.

Zjawiska politycznej apatii czy alienacji stanowią charakterystyczną cechę tendencji, którym - z różnym natężeniem - podlegają wszystkie społeczeństwa. Wielu autorów określa współczesne zachodnie społeczeństwa mianem zdepolityzowanych (Terrén, 2002, s. 167), często silniej akcentując apatyczność młodego pokolenia (Tyyskä, 2009, s. 151). Takie wyjaśnienie wydaje się o tyle racjonalne, że zmiana normatywna, której doświadczały owe społeczeństwa w latach 70 . XX wieku (w kierunku większej akceptacji wartości postmaterialistycznych) i wiążące się z nią konsekwencje (jak np. upadek hierarchicznych autorytetów) silniej odcisnęły się na postawach ludzi młodych. To oni, wychowując się w warunkach gwarantowanych przez państwo dobrobytu (bezpieczeństwo fizyczne i socjalne) utrwalili wzory zachowań, w których istotne miejsce zajmuje dystans wobec formalnej - tradycyjnie rozumianej - polityki (Inglehart, 1999, s. 236). Depolityzacja jest określeniem, które równie dobrze opisuje sytuację w krajach postkomunistycznych. Tam również, jeszcze wciąż, doświadczamy przemian w zakresie akceptowanych norm i hierarchii wartości, które w określony sposób wpływają na politykę (np. na strukturę dyskursów politycznych czy nawet skład elity parlamentarnej). Hanna Palska opisuje ten proces w następujący sposób: „Wzory, mody, subkultury zachodnie, po zburzeniu politycznej tamy, zmieniły dekorację polskiej codzienności nieomal z dnia na dzień" (Palska, 2009, s. 122). Delegitymizacja autorytetów takich jak: szkoła, państwo, partie polityczne czy kościół sprzyja utrwalaniu postaw zdystansowanych wobec polityki. W tym przypadku ważną rolę odgrywa jeszcze inny czynnik. Młode pokolenie, urodzone po 1989 roku, traktuje państwo i system polityczny, w którym żyje jako element świata zastanego, o który nie trzeba zabiegać, który jest czymś naturalnym. Stąd być może słabość oddziaływania na młodzieżowe postawy takich kategorii, jak obowiązek obywatelski czy odpowiedzialność za państwo ${ }^{2}$.

Perspektywa zmiany społecznej, która skutkuje metamorfozą postaw w najważniejszych wymiarach ludzkiej aktywności jest tą, której warto przyjrzeć się nieco bliżej (O'Toole, Gale, 2013, s. 32-33). Refleksję w tym nurcie prowadzi w swoich pracach Eduardo Terrén. Jego zdaniem, wszystkie negatywne aspekty obecności obywateli w sferze publicznej czy politycznej (obojętność i apatia) są wynikiem tego normatywnego przesunięcia. Jak twierdzi, zmiany, którym podlegają współczesne społeczeństwa na trwałe przeorganizowały ludzkie nawyki i sposoby bycia (także myślenia i postrzegania) na różnych polach aktywności (ekonomia, polityka, kultura). Pisze wręcz o „,nowoczesnym stylu życia”, który „,wymusza postawy dotyczące sfery pracy, polityki i kultury, które sprawiaja, że osobista tożsamość jest kształtowana w nowoczesny sposób" (Terrén, 2002, s. 162) (zob. tab. 1). Postmodernistyczna współczesność wzmacnia rozprzestrzenianie się postaw, które „zagrażają doświadczeniu nowoczesnego obywatelstwa”, o którym - twierdzi Terrén - trzeba mówić raczej w kategoriach ,zdemotywowanego obywatelstwa" (demotivated citizenship) (Terrén, 2002, s. 174).

\footnotetext{
${ }^{2} \mathrm{~W}$ tym miejscu trzeba dodatkowo zauważyć, że nie są to również wartości szczególnie cenione przez pokolenie starsze (rodziców), w związku z czym brak odpowiedniego wzorca obywatelskiego działania stanowi istotną barierę dla upowszechniania się takich postaw wśród ludzi młodych.
} 
Tabela 1

Postawy postmodernistyczne w poszczególnych obszarach aktywności ludzkiej

\begin{tabular}{||l|l|l||}
\hline \multicolumn{1}{|c|}{ Obszar aktywności } & \multicolumn{1}{c|}{ Glówne aktywności } & \multicolumn{1}{c|}{ Postmodernistyczne postawy } \\
\hline Ekonomia & Praca & Zniechęcenie i demotywacja \\
\hline Polityka & Partycypacja & Obojętność i apatia \\
\hline Kultura & Zrozumienie i identyfikacja & Relatywizm i esencjalizm ${ }^{3}$ \\
\hline
\end{tabular}

Źródło: (Terrén, 2002, s. 163).

\section{Koncepcja stylu życia}

Pojęcie ,stylu życia”, jak pisze Małgorzata Jacyno, „,odnosi się do wielu różnych sposobów funkcjonowania na co dzień, a ich zróżnicowanie stanowi konfigurację wyborów związanych z systemem wartości, relacjami i codziennymi praktykami” (Jacyno, 2012, s. 274). Pewne istotne elementy tej koncepcji pojawiają się już w pracach Maxa Webera (Weber, 1975), Thorsteina Veblena (Veblen, 1971), Norberta Eliasa (Elias, 2011) czy Pierre'a Bourdieu (Bourdieu, 2005). Na potrzeby niniejszego artykułu dokonano konceptualizacji tego pojęcia w oparciu o podejście Andrzeja Sicińskiego. Celem tego zabiegu jest wyjście poza stricte socjologiczne ujęcie stylu życia i zaproponowanie tej kategorii jako użytecznego narzędzia do analizowania roli i miejsca polityki w życiu codziennym obywateli.

Według Sicińskiego styl życia ,jest określeniem, które odnosić można zarówno do zbiorowości społecznych, jak i jednostek. Oznacza ono zespół codziennych zachowań (sposób „postępowania”, aktywność życiowa), specyficzny dla danej zbiorowości lub jednostki (treść i konfigurację owych zachowań); a inaczej mówiąc: charakterystyczny sposób bycia odróżniający daną zbiorowość lub jednostkę od innych" (Siciński, 2002, s. 22-23). Ta perspektywa jest stosowana przez autora konsekwentnie w różnych opracowaniach. W innym miejscu pisze bowiem: „to specyficzny zespół codziennych zachowań członków owej zbiorowości, stanowiący manifestację ich położenia społecznego, a dzięki temu umożliwiający ich społeczną identyfikację" (Siciński, 1978, s. 14). Z powyższych definicji wyłaniają się przynajmniej dwie kluczowe właściwości. Z jednej strony jest to kwestia podmiotowości stylu życia. Irena Wolska-Zogata pisze bardziej ogólnie, że stanowią go „czynności specyficzne dla pewnych socjologicznie wyodrębnionych całości” (Wolska-Zogata, 2009, s. 161). Dlatego też można mówić o stylu życia konkretnych jednostek, ale przede wszystkim większych kategorii społecznych, np. o stylu życia młodego pokolenia czy całego społeczeństwa. Z drugiej strony, elementem znaczącym jest tutaj kategoria codzienności. Jak stwierdza Elżbieta Tarkowska, „wręcz definicyjnym elementem koncepcji stylu życia wypracowanej w ramach tego programu badawczego jest codzienność, kategoria życia codziennego, codzienne zachowania ludzi” (Tarkowska, 2009, s. 145). Sam Siciński tak wyjaśniał znaczenie tej kategorii: „Za-

\footnotetext{
${ }^{3} \mathrm{~W}$ podejściu do kultury autor jako demokratyczną proponuje postawę wynikającą z równego dystansu tak wobec asymilacjonizmu, jak i skrajnego multikulturalizmu (Terrén, 2002, s. 173).
} 
chowania codzienne to te, które mają rutynowy charakter w życiu danej jednostki, grupy społecznej, zbiorowości; są powtarzane, gdy powtarzają się [...] określone sytuacje, okoliczności [...]. Przeciwieństwem określenia «codzienny» w takim rozumieniu będą więc określenia «wyjątkowy», «niezwykły», «uroczysty» itp." (Siciński, 2002, s. 22). Ów akcent na rutynowe działania ludzi kładzie także Anthony Giddens w swojej propozycji definicji stylu życia, który stanowi „mniej lub bardziej zintegrowany zespół praktyk, które podejmuje jednostka nie tylko dlatego, że są użyteczne, ale także dlatego, że nadają materialny kształt poszczególnym narracjom tożsamościowym" (Giddens, 2012, s. 115). Styl życia to także coś więcej niż sposób bycia (zredukowany jedynie do aspektu behawioralnego). W gruncie rzeczy, na styl życia składają się: ,zachowania ludzi zróżnicowane co do zakresu i formy [...]; motywacje owych zachowań (przypisywane im znaczenia i wartości); a także pewne funkcje rzeczy będących bądź rezultatami, bądź celami, bądź instrumentami owych zachowań [...]" (Siciński, 2002, s. 23). Zdaniem autora pojęcie to obejmuje - obok zachowan - także „psychofizyczne mechanizmy leżące u podstaw owych zachowań: ludzkie motywacje, potrzeby, akceptowane wartości" (Siciński, 1978, s. 14; zob. Kokociński, 2001, s. 97). Ludzie kształtują swoje style życia, dokonując wyboru z pewnego repertuaru możliwości działania ${ }^{4}$. Wybór ów - chociaż w teorii wolny - podejmowany jest zwykle w różnych sytuacjach, w sposób mniej lub bardziej świadomy, zdeterminowany poziomem własnych zasobów (np. wiedzy) (Siciński, 1988, s. 55). Kształtowany jest $w$,,procesie wzajemnego oddziaływania bardzo szeroko pojętych warunków życia oraz indywidualnych wzorów zachowań zdeterminowanych przez czynniki społeczno-kulturowe 5 i cechy osobiste jednostek" (Wilk, 2003, s. 47).

Czy kategoria stylu życia może być pomocna w politologicznym opisie i wyjaśnianiu ludzkich zachowań? Przyjęta tutaj koncepcja dowodzi, że tak. Andrzej Siciński, pośród dziedzin, w których można poszukiwać elementów stylu życia - obok takich spraw jak: budżet czasu, praca, konsumpcja dóbr materialnych, zdrowie, potrzeby intelektualne i estetyczne, rekreacja, stosunek do religii czy relacje międzyludzkie - wymienia uczestnictwo w życiu społeczno-politycznym, podkreślając ,postawy wobec spraw publicznych” (Siciński, 1978, s. 15-16; Tarkowska, 2009, s. 146; Wolska-Zogata, 2009, s. 160). Właśnie dlatego warto odwołać się do tej koncepcji, przyjmując perspektywę politologiczną. Wówczas większy nacisk kładziemy na politykę jako kategorię mniej lub bardziej istotną w życiu codziennym. Nasza uwaga skupia się nie tyle na zachowaniach „szczególnych” czy „wyjątkowych” (jak np. głosowanie w wyborach), ale „rutynowych”, ,zwyczajnych” (np. na częstotliwości rozmów z rodziną czy znajomymi na tematy polityczne).

\section{Metodologia badania}

Badając style życia w sposób oczywisty należy dostrzegać zróżnicowanie - zachowań i ich motywacji, które występują w ramach określonych zbiorowości, na przykład w ra-

\footnotetext{
${ }^{4}$ Styl życia jest „przejawem jakiejś zasady [...] wyboru codziennego postępowania spośród repertuaru zachowań możliwych w danej kulturze" (Siciński, 2002, s. 32).

${ }^{5}$ Nie można w tym miejscu pomijać roli środków masowego komunikowania.
} 
mach społeczeństwa (Siciński, 1978, s. 11). Trudno zakładać, że zawsze wszyscy członkowie danej grupy społecznej powielają ten sam zestaw zachowań i w podobny sposób motywują swoją aktywność. Na jeden z wymiarów tej różnorodności zwraca uwagę Hanna Palska, opisując przemiany społeczne w Polsce po 1989 roku: ,Jedna Polska, sztucznie ujednolicona $\mathrm{w}$ okolicznościach sztucznie powodowanych decyzjami politycznymi dawnego reżimu, w warunkach wolnego rynku szybko się różnicuje i na różnych poziomach te różnice manifestuje. Po dwóch badanych stronach stają ludzie dwóch odmiennych, jeśli jeszcze nie kultur, to stylów działania, wyobrażeń o swoich możliwościach, koncepcji rzeczywistości społecznej i swego w niej miejsca" (Palska, 2009, s. 134). Samo różnicowanie odbywa się na wielu różnych płaszczyznach, m.in. ekonomicznej, politycznej czy społeczno demograficznej (biorąc pod uwagę choćby kryterium wieku) (Giddens, 2012, s. 117). To implikuje perspektywę, w której - aby nie zakłamywać rzeczywistości - będziemy często mówić o dominującym stylu życia, tzw. dominującym układzie wzorców (Fatyga, 2009, s. 151).

Samo diagnozowanie stylów życia - jak przekonuje Elżbieta Tarkowska - powinno opierać się na interdyscyplinarnym podejściu. Główną przesłanką ku temu jest złożoność przedmiotu badań, tj. życia codziennego (Tarkowska, 2009, s. 146). Z drugiej strony, konsekwencją pewnego koniecznego kompromisu jest to, że „opis konkretnego stylu życia nie tylko nie obejmuje wszystkich dziedzin i typów zachowań, ale - co więcej - nie obejmuje nawet zachowań rozpowszechnionych, o ile nie są one czymś wyróżniającym dany styl życia spośród stylów życia analogicznych podmiotów" (Siciński, 1978, s. 16-17). W niniejszym artykule - do opisu jednego z elementów stylu życia młodzieży - wykorzystano dane ilościowe z międzynarodowych projektów badawczych: Europejskiego Sondażu Społecznego (European Social Survey, edycja 4. i 5. z 2008 i 2010 roku), Europejskiego Badania Wartości (European Values Study, ostatnia edycja z 2008 roku) oraz Eurobarometru (m.in. specjalne badanie Flash Eurobarometer 202 - Young Europeans z 2007 roku). Wykorzystane informacje wygenerowano ze statystycznych baz danych, uwzględniając kryterium wieku 18-24 lata. Pozwoliły one wytypować szereg wskaźników, które posłużyły do opisu roli, jaką polityka odgrywa w życiu codziennym młodych obywateli (Polaków i mieszkańców Unii Europejskiej). Do analizy wybrano następujące wskaźniki:

1) zainteresowanie polityką;

2) ważność polityki w hierarchii spraw codziennych;

3) częstotliwość śledzenia wiadomości politycznych w mediach;

4) częstotliwość rozmów na tematy polityczne;

5) częstotliwość przekonywania do swoich poglądów osób z najbliższego otoczenia;

6) stopień trudności w kształtowaniu własnej opinii na tematy polityczne;

7) poczucie skomplikowania polityki;

8) aktywność w czasie wolnym;

9) aktywność w organizacjach o charakterze dobrowolnym.

Mimo że powyższy wybór dosyć dokładnie oddaje specyfikę ważnego dla autora aspektu stylu życia młodzieży, to ma on charakter autorytatywny i także dlatego może podlegać dyskusji. 


\section{Depolityzacja jako element stylu życia młodych Polaków}

Niektórzy badacze zwracają większą uwagę na negatywne aspekty współczesnego stylu życia młodzieży. Maciej Kokociński wymienia m.in. takie cechy jak: zmiany w systemie wartości, wzrost przestępczości, alkoholizm, narkomanię, spadek autorytetu rodziców i roli rodziny oraz znaczenia szkoły jako środowiska wychowawczego (Kokociński, 2001, s. 97). W polu ,postaw wobec spraw publicznych” należałoby dodatkowo uwzględnić zjawisko depolityzacji. W niniejszym artykule będzie ono rozumiane jako: słabnące znaczenie polityki w hierarchii spraw ważnych w życiu młodego człowieka, słabe zainteresowanie i stopień poinformowania o polityce, brak orientacji w zjawiskach i wydarzeniach politycznych, słaba reprezentacja polityki jako tematu konwersacji $\mathrm{w}$ relacji z najbliższym otoczeniem, a także brak aktywności o profilu politycznym w strukturze czasu wolnego czy aktywność społeczna skoncentrowana głównie na działalności o niepolitycznym charakterze. Analiza zgromadzonych danych w dużej mierze potwierdza założenie, iż młodzi ludzie (zarówno w Polsce, jak i przeciętnie w Unii Europejskiej) w znaczącym stopniu reprezentują „zdepolityzowany” styl życia.

Wartości pierwszego z wybranych wskaźników nie powinny zaskakiwać (wykres 2). Polityka nie jest dzisiaj tematem, który szczególnie interesuje ludzi młodych. Jeśli chodzi o młodych Polaków, to tylko $29 \%$ z nich deklaruje jakiekolwiek zainteresowanie, z czego tylko $6 \%$ bardzo interesuje się aktualnymi wydarzeniami o charakterze politycznym. $\mathrm{Z}$ drugiej strony, aż $72 \%$ przyznaje się do braku zainteresowania polityką. Bardzo podobne proporcje odnajdujemy w przypadku młodych mieszkańców UE. Trzeba założyć, że niski stopień ciekawości implikuje mniejszą orientację i niższy poziom wiedzy na tematy polityczne, a więc słabsze tzw. polityczne wyrobienie (political sophistication). W gruncie rzeczy należy więc mówić o swoistym zamkniętym cyklu następstw. Słabsze wyrobienie warunkuje z kolei mniejszą częstotliwość politycznej aktywności. Wydaje się

\section{Wykres 2. Poziom zainteresowania polityką wśród młodzieży w UE}

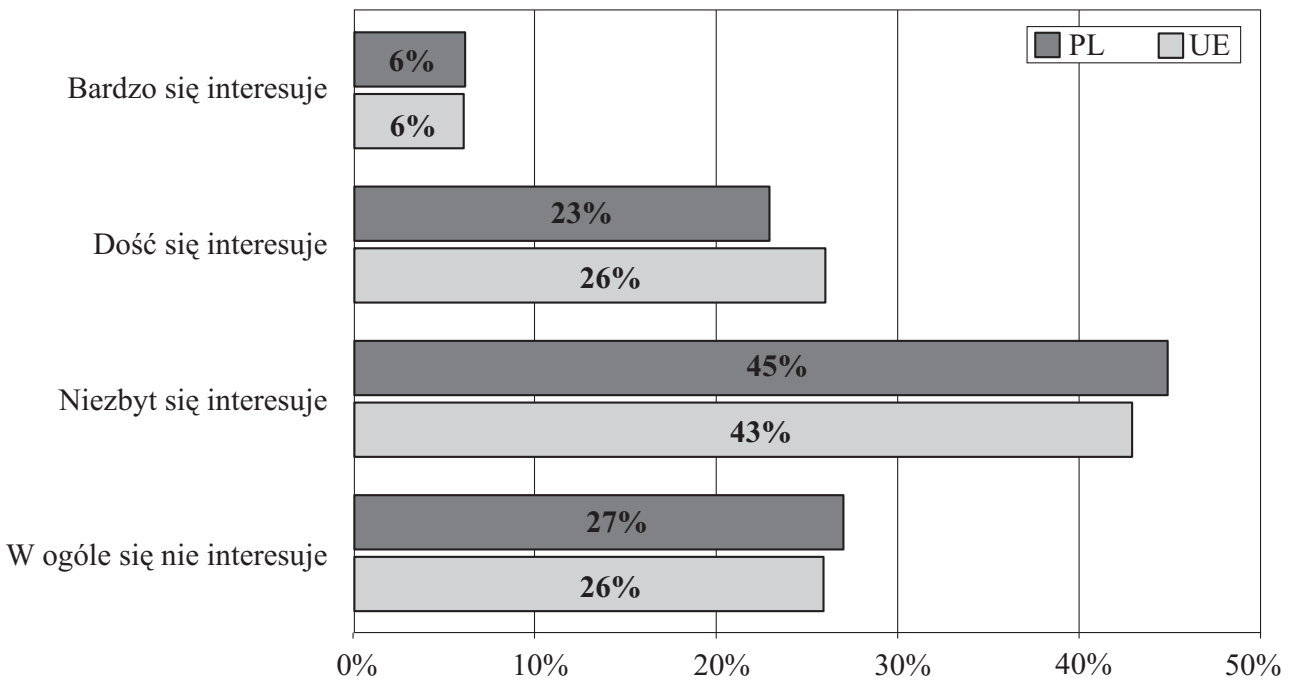

Źródło: Opracowanie własne na podstawie danych ESS Round 5. 
zasadnym wyjaśnienie, że to politycy, ale i dziennikarze (publicyści) - narzucając w publicznych debatach treści i styl nieakceptowany przez młode pokolenie - sprawiają, że polityka staje się tematem wypieranym (bo mało atrakcyjnym) spośród priorytetów codzienności młodego człowieka.

Opisane powyżej zjawisko zostało bardziej szczegółowo zilustrowane na wykresie 3. Przedstawia on hierarchię ważności spraw w życiu młodych Polaków. Wśród sześciu wymienionych (rodzina, przyjaciele i znajomi, czas wolny, praca, religia, polityka), to polityka wskazywana jest najczęściej jako „nieważna”. Marginalne znaczenie ma ona dla $78 \%$ polskiej młodzieży. Nieco odmiennie rozkładają się opinie młodych Europejczyków, chociaż i oni nie postrzegają polityki jako istotnej wartości. 72\% z nich uznaje politykę za sprawę bez większego znaczenia.

\section{Wykres 3. Hierarchia ważności spraw w życiu młodych obywateli Polski}

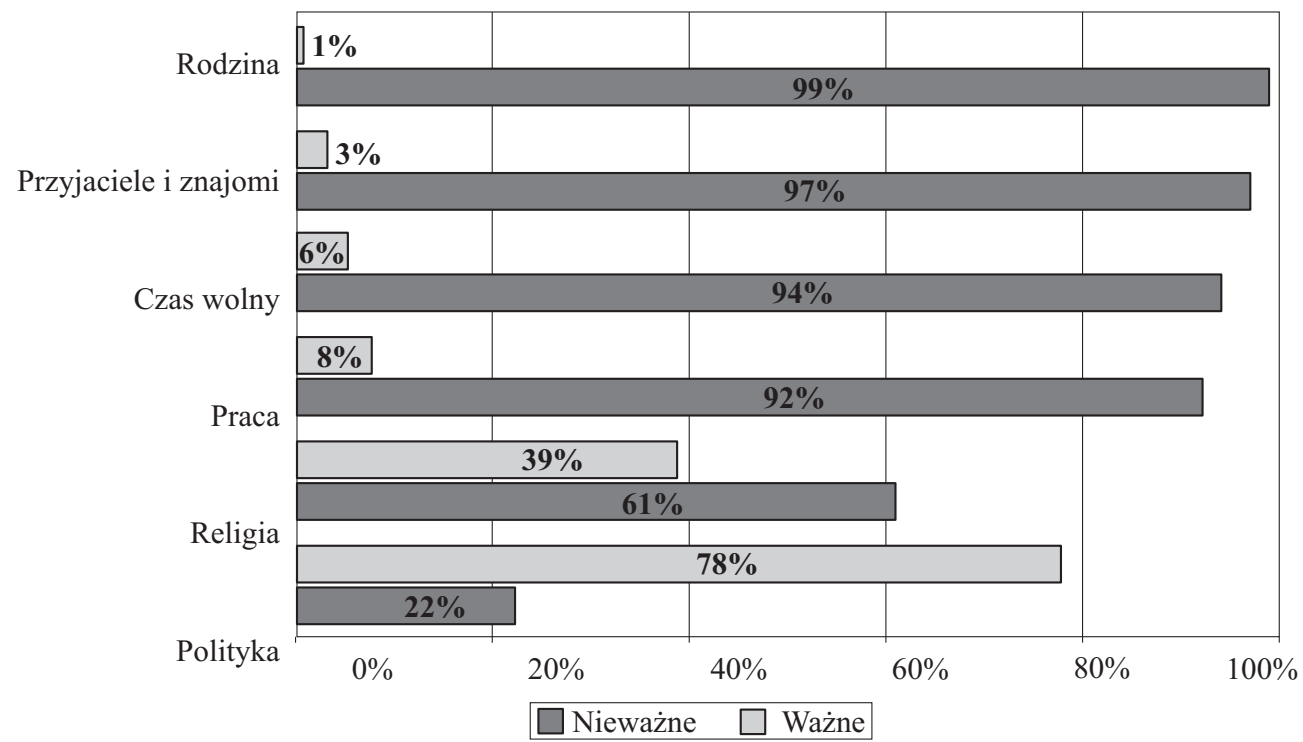

Źródło: Opracowanie własne na podstawie danych EVS 2008.

Wspomniano już o tym, że brak zainteresowania polityką może implikować słabszą motywację do poszukiwania informacji na tematy polityczne. Na to zjawisko można również spojrzeć od drugiej strony. Mniej - dodatkowo słabszej jakości - informacji sprawia, że trudno jest rozbudzić w młodym człowieku zainteresowanie polityką. Okazuje się, że w praktyce mniej niż jedna piąta młodych Polaków i dokładnie jedna czwarta Europejczyków śledzi wiadomości polityczne w mediach masowych na co dzień (tabela 2). Współcześnie pojęcie mediów należy rozumieć szeroko, zaliczając w ich zakres także pozyskiwanie różnej jakości informacji z Internetu. Kilka razy w tygodniu na wiadomości polityczne natrafia kolejne $25 \%$ polskiej i $24 \%$ europejskiej młodzieży. Niemal połowa młodych Polaków (48\%) pozyskuje wiedzę o polityce sporadycznie, a prawie co dziesiąty (9\%) - deklaruje, że nie zdarza mu się poszukiwanie tego rodzaju wiedzy (takich osób w całej UE jest więcej - 12\%). 
Częstotliwość śledzenia przez młodych obywateli wiadomości politycznych w mediach masowych

\begin{tabular}{|c|c|c|}
\hline & Polska & UE \\
\hline Codziennie & $18 \%$ & $25 \%$ \\
\hline Kilka razy w tygodniu & $25 \%$ & $24 \%$ \\
\hline Raz lub dwa razy w tygodniu & $19 \%$ & $17 \%$ \\
\hline Rzadziej & $29 \%$ & $23 \%$ \\
\hline Nigdy & $9 \%$ & $12 \%$ \\
\hline
\end{tabular}

Źródło: Opracowanie własne na podstawie danych EVS 2008.

Kolejnym istotnym wskaźnikiem, który nakazuje mówić o depolityzacji jako elemencie stylu życia młodzieży jest częstotliwość rozmów na tematy polityczne z przyjaciółmi, znajomymi lub rodziną (wykres 4). Jest rzeczą oczywistą, że ludzie zainteresowani określonym problemem, posiadający dużą orientację w jego „meandrach”, posiadający wiedzę na dany temat, chętniej będą inicjowali, a także uczestniczyli w dyskusjach, których przedmiot stanowi ów problem czy temat. Dlatego też - w świetle zaprezentowanych powyżej danych - zrozumiały jest fakt, że niewielka część polskiej (7\%) i europejskiej (13\%) młodzieży często podejmuje rozmowy na tematy polityczne z osobami z najbliższego otoczenia. Ponad połowa (Polska: 56\%, UE: 55\%) stwierdza, że czasami takie tematy pojawiają się $\mathrm{w}$ treści rozmów $\mathrm{z}$ najbliższymi. W tym przypadku trudno jednak ocenić szczegółowość tej kategorii odpowiedzi (raz na tydzień? Raz na miesiąc? Przed

\section{Wykres 4. Częstotliwość rozmów młodzieży na tematy polityczne z przyjaciółmi,} znajomymi lub rodziną

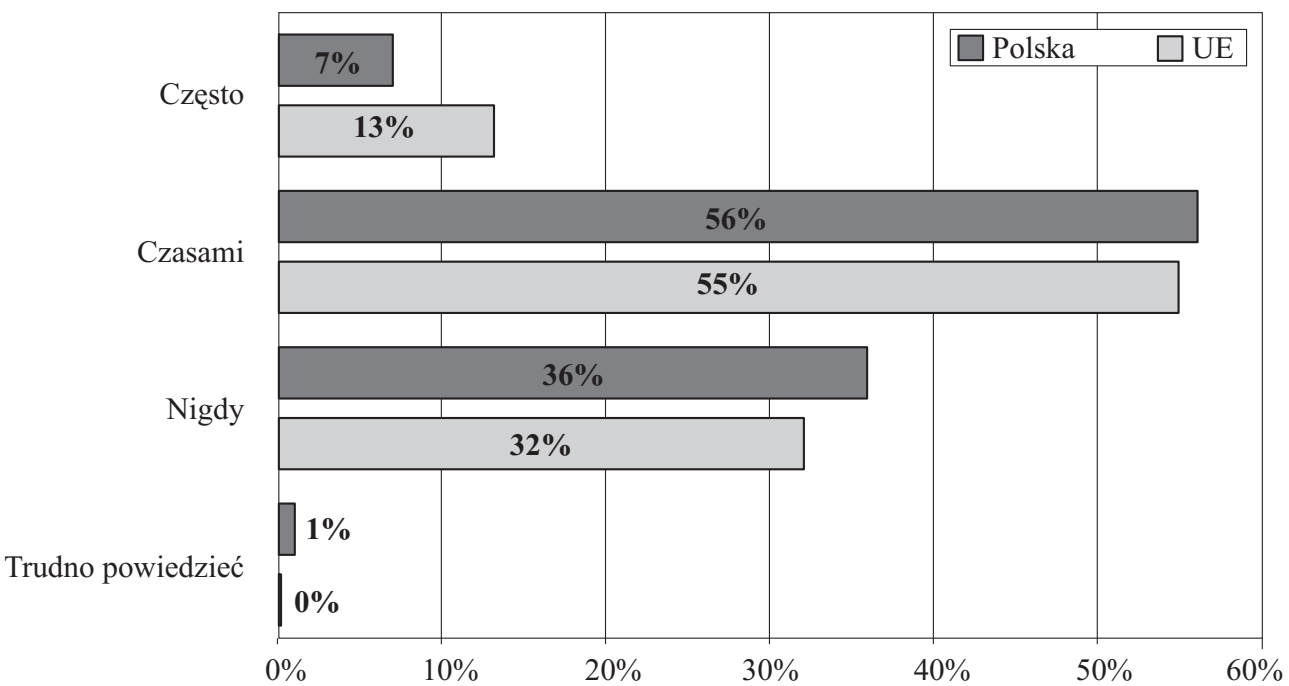

Źródło: Opracowanie własne na podstawie danych EB 75.3. 
kolejnymi wyborami?), jak również czego konkretnie dotyczą owe dyskusje (konkretnych wydarzeń? Personaliów? Czy są to np. jedynie tzw. żarty polityczne?). Z kolei około jednej trzeciej młodych Polaków (36\%) i mieszkańców UE (32\%) wyraża opinię, że w ogóle nie rozmawia na tematy związane z polityką.

Młodzi Polacy jeszcze rzadziej (tylko 3\% z nich) inicjują takie dyskusje, w których intencją jest przekonywanie do swoich poglądów przyjaciół czy krewnych (wykres 5). Takie nakłanianie innych do swoich poglądów wymaga z pewnością większej orientacji $\mathrm{w}$ temacie, a także umiejętności argumentowania. Ta natomiast wynika z poziomu wiedzy na tematy polityczne. Jednakże sama polityka - jako dziedzina mało atrakcyjna - coraz rzadziej bywa tematem codziennych (na gruncie rodzinnym lub zawodowym) konwersacji. Większość młodych (zarówno w Polsce, jak i UE) przyznaje, że jedynie raz na jakiś czas zdarza im się perswadować na rzecz określonych poglądów politycznych. Prawie jedna trzecia młodych Polaków (30\%) i jedna piąta Europejczyków (18\%) zupełnie unika takich sytuacji.

Wykres 5. Częstotliwość przekonywania do swoich poglądów przyjaciól, krewnych, kolegów z pracy

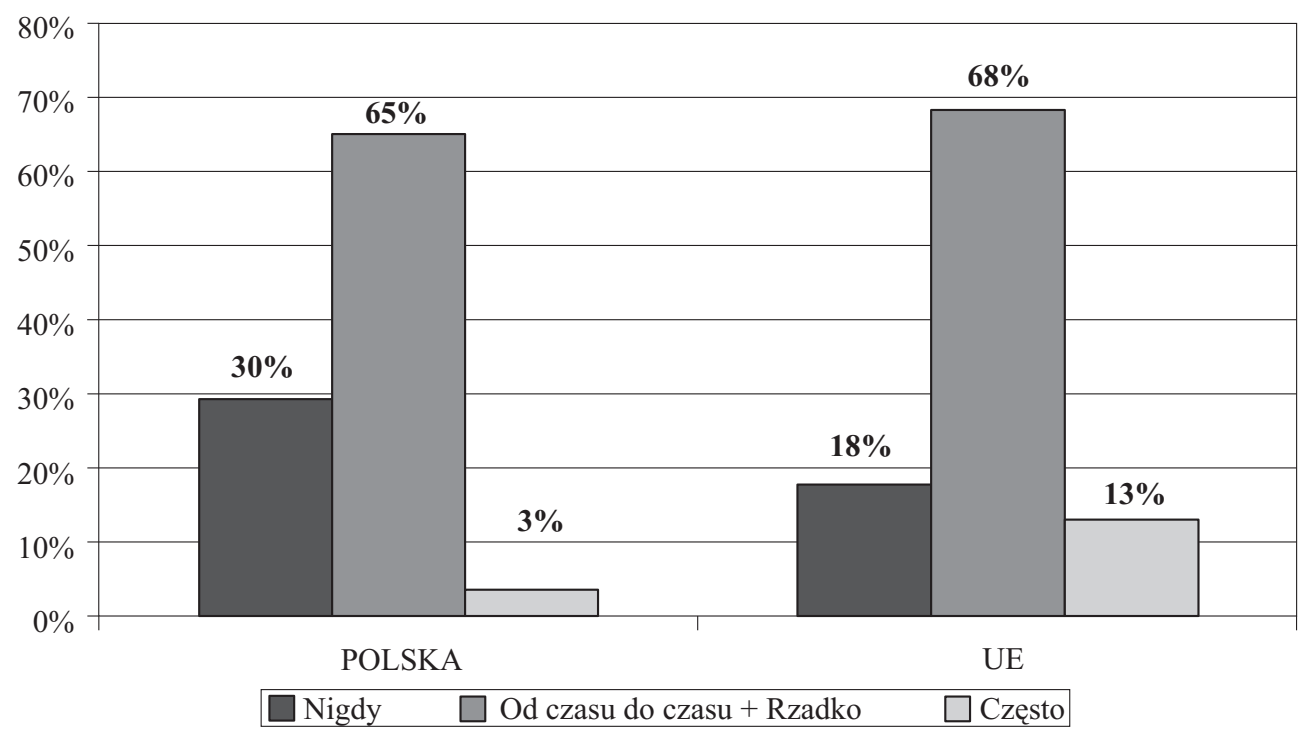

Źródło: Opracowanie własne na podstawie danych $E B$ 75.3.

Młody obywatel częściej organizuje swoje życie dystansując się od tego, co polityczne także dlatego, że nie potrafi zrozumieć tego czym jest i jak funkcjonuje system polityczny (wykres 6). Co ciekawe, Polacy w wieku 18-24 lata częściej (32\%) niż statystyczni młodzi Europejczycy (24\%) przyznają, że formułowanie opinii na tematy polityczne przychodzi im ze względną łatwością. Brak opinii czy trudność w jej kształtowaniu - podobnie jak w poprzednich przykładach - jest zarówno przyczyna, jak i skutkiem młodzieżowego stosunku do polityki. W tym przypadku należy jednak dostrzec swoisty deficyt racjonalności tak przydatnej ,światłemu” (dobrze poinformowanemu) 
obywatelowi. Niemal tyle samo osób stwierdza, że ma problem ze sformułowaniem własnej opinii w kwestiach politycznych (wśród młodych Polaków: 31\%, a pośród mieszkańców UE jeszcze więcej: 37\%). Dodatkowo, trzeba uwzględnić niemal 40-procentową grupę osób, w opinii której wyrobienie sobie opinii w tym zakresie nie jest ,ani łatwe, ani trudne", co świadczy raczej o próbie ucieczki od udzielenia odpowiedzi na ten temat.

\section{Wykres 6. Stopień trudności ksztaltowania własnej opinii młodzieży na tematy polityczne*}

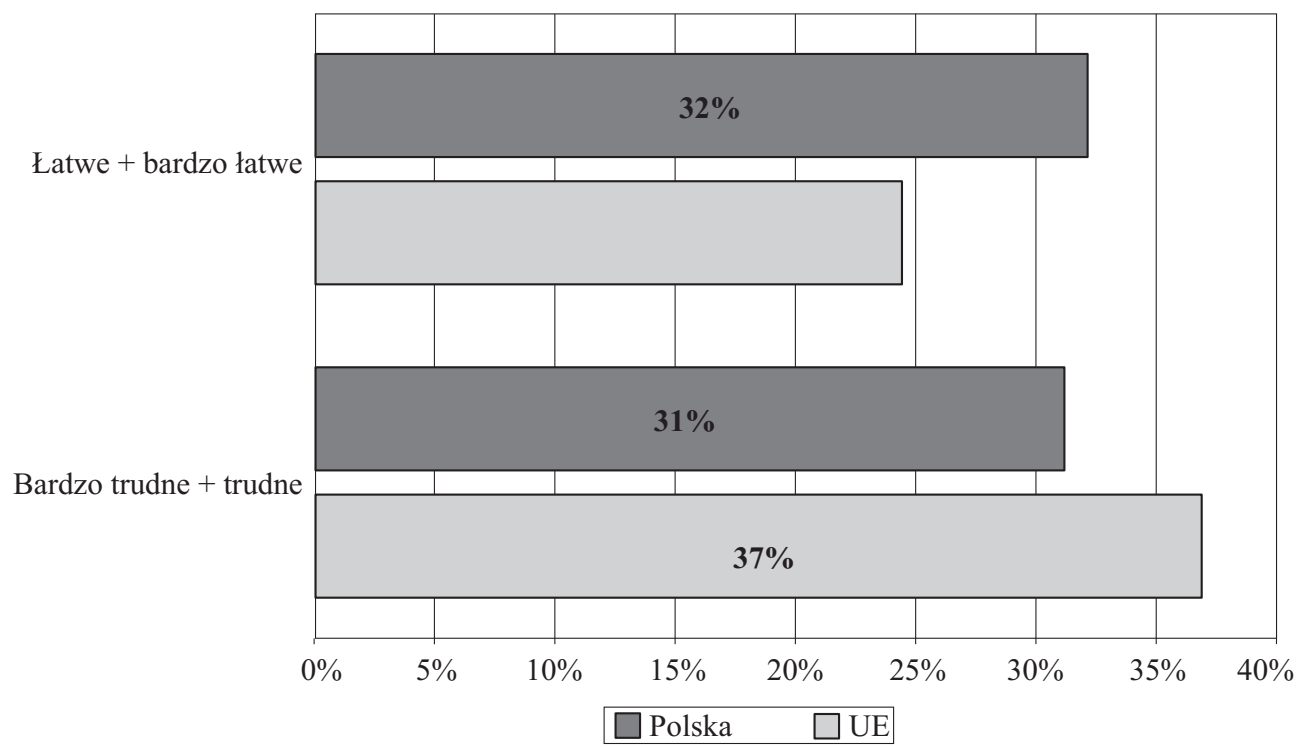

* Na wykresie pominięto środkową kategorię odpowiedzi „Ani trudne, ani łatwe”, dla której rozkłady przedstawiały się następująco: POLSKA: 37\%, UE: 39\%.

Źródło: Opracowanie własne na podstawie danych ESS Round 4.

Potwierdzeniem tego zjawiska jest rozkład odpowiedzi na pytanie o to, na ile współczesna polityka jest tak skomplikowana, że trudno zrozumieć (wykres 7). Proporcje są bardzo podobne. Zbyt duże skomplikowanie dostrzega od 35\% (Polska) do 37\% (UE) młodych ludzi. Dobrą orientację - przynajmniej deklaratywnie - posiada od 22\% (tym razem UE) do 26\% (Polska). Ponownie największą grupę stanowią respondenci udzielający odpowiedzi niejednoznacznych (typu: „od czasu do czasu polityka jest skomplikowana"). Tematy, sprawy czy zjawiska niezrozumiałe - a taką jest polityka dla znacznej części młodego pokolenia - nie wzbudzają też ciekawości. Polityka w swej czystej postaci (jako tzw. hard news - informacje dotyczące najważniejszych spraw) stanowi dziedzinę mało atrakcyjną (mimo że jako element tzw. soft news czy popkultury bywa akceptowana $^{6}$ ).

\footnotetext{
${ }^{6}$ Przykładem jest oglądalność seriali telewizyjnych, których motywem przewodnim są kulisy polityki.
} 
Wykres 7. Postrzegany przez młodzież stopień skomplikowania polityki*

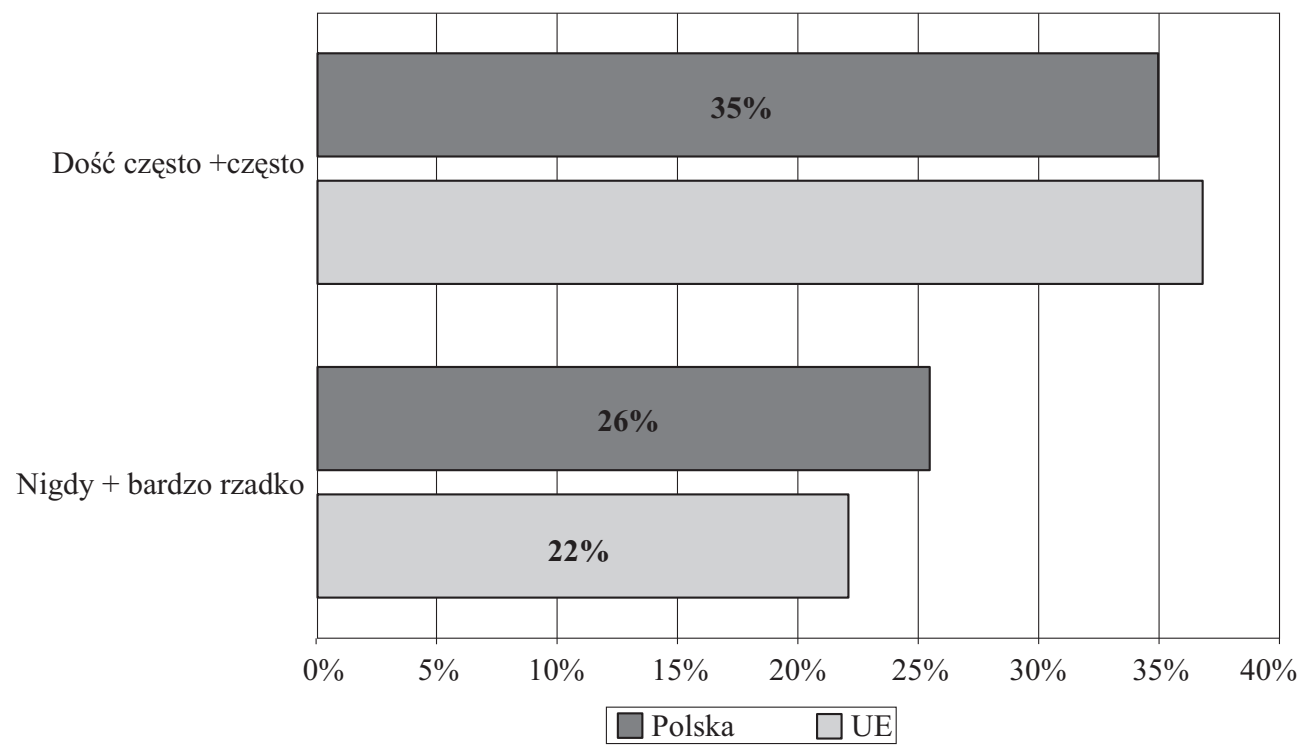

* Na wykresie pominięto środkową kategorię odpowiedzi „Od czasu do czasu”, dla której rozkłady przedstawiały się następująco: POLSKA: 39\%, UE: $41 \%$.

Źródło: Opracowanie własne na podstawie danych ESS Round 4.

Jednym z najtrafniejszych wskaźników depolityzacji w stylu życia młodzieży jest poziom aktywności w czasie wolnym. Na wykresie 8 przedstawiono hierarchię działań, jakim młodzi mieszkańcy Unii Europejskiej poświęcają czas wolny od nauki czy pracy. Pośród najczęściej wymienianych aktywności znajdują się te związane z odpoczynkiem, sportem, poszukiwaniem relaksu, spokoju, towarzystwa, rozrywki. Widać wyraźnie, że tych wartości młodzi ludzie poszukują albo w sposób bezpośredni - spotkania ze znajomymi, rodziną - albo pośredni - korzystanie z mediów (Internet, telewizja, radio). Z kolei jedyny przykład w zestawieniu, który dotyczy działalności społecznej czy politycznej (a więc jest zorientowany na pewną wspólnotę, środowisko, w którym żyje jednostka) pojawia się na ostatnim miejscu. Zaledwie 2\% młodych Europejczyków poświęca swój wolny czas na pracę wolontariacką czy pracę na rzecz społeczności lokalnej.

Depolityzacja widoczna jest również w strukturze tych działań społeczno-politycznych, które rzeczywiście są podejmowane (bez względu na ich częstotliwość). Punktem odniesienia jest tutaj przynależność młodych ludzi do organizacji o charakterze dobrowolnym (tabela 3). Po pierwsze, trzeba zauważyć, że największą grupę stanowią osoby pozostające bez związku z jakąkolwiek organizacją tego rodzaju. W Polsce jest ich zdecydowanie więcej (aż 75\%) niż średnio w UE (44\%). Drugie ważne spostrzeżenie wyłania się z analizy tych organizacji, które cieszą się największą popularnością. W aktywności młodych Polaków oraz mieszkańców UE widać istotne analogie (podobny rozkład), przy czym ogólny poziom partycypacji jest nieporównywalny. Wniosek jest jednoznaczny: młodzi ludzie, jeśli się angażuja, to głównie w działalność o niepolitycznym charakterze. Najczęściej są to dziedziny związane ze sportem i rekreacją, nauką, 


\section{Wykres 8. Aktywność młodzieży w czasie wolnym (mieszkańcy UE)}

Idę na spacer, na przejażdżkę rowerowa, uprawiam sport

Spotykam sie z przyjaciółmi, idę potańczyć, na drinka, coś zjeść

Czytam

Używam Internetu, gram w gry video

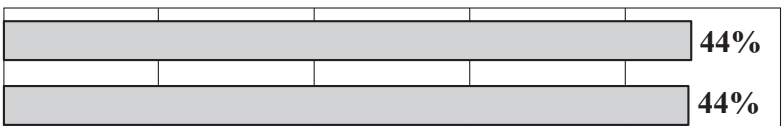

Idę do kina, teatru lub na koncert

Pomagam w domu Idę na zakupy

Wykonuję pewną pracę zarobkową

Gram na instrumencie

Uczestniczę w pracy wolontariackiej/ na rzecz lokalnej społeczności

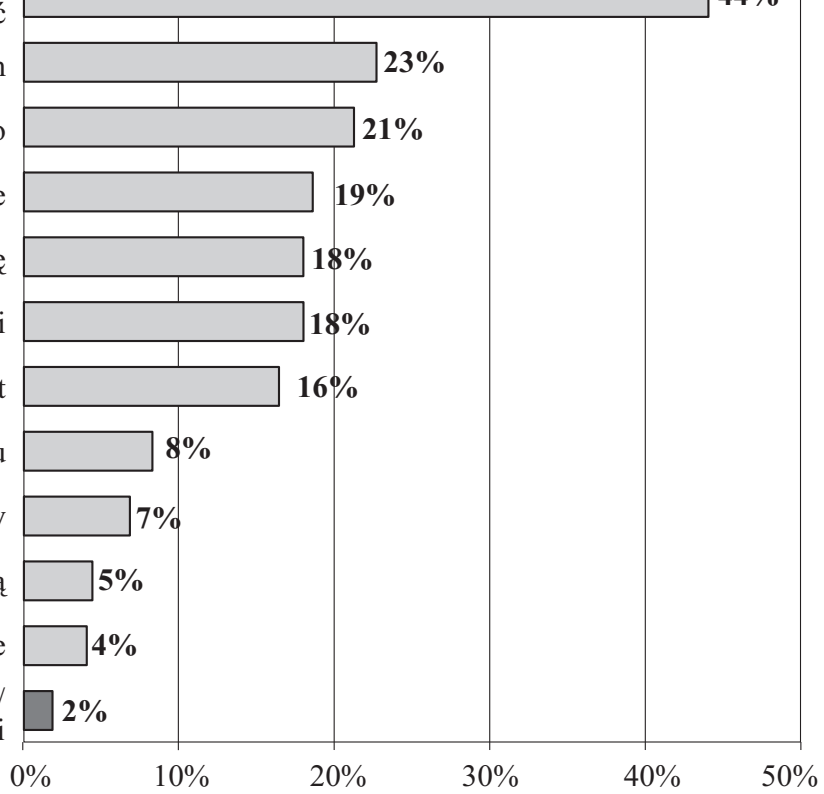

* Odsetki nie sumują się do $100 \%$ ponieważ respondenci mogli wskazać więcej niż 1 odpowiedź.

Źródło: Opracowanie własne na podstawie danych Flash EB 202.

sztuka, muzyka, kulturą, organizacje młodzieżowe oraz religijne lub kościelne. Z kolei te związane ze sferą polityczną czy nawet społeczną (partie lub stowarzyszenia polityczne, organizacje charytatywne, lokalne, kobiece, pokojowe) wymieniane są najrzadziej. Nieatrakcyjność polityki (ale również jej niewiarygodność i niezrozumienie) powoduje, że młodzi ludzie - jeśli już formalizują swoją aktywność - to przede wszystkim z dala od niej. Zaprezentowane w tym miejscu dane nie uprawniają do wysunięcia tezy, że partycypacja obywatelska jest pomysłem na życie młodego człowieka. W praktyce życia społecznego widać raczej zjawisko indywidualizacji, ale również przygodności różnych form uczestnictwa. Cechą charakterystyczną tego stylu życia jest dodatkowo odrzucenie polityki jako przestrzeni, w której można realizować swoje potrzeby czy zainteresowania.

Tabela 3

Przynależność młodych obywateli do dobrowolnych organizacji*

\begin{tabular}{||l|c|c||}
\hline \multicolumn{1}{|c|}{1} & Polska & UE \\
\hline Organizacje opiekujące się osobami starszymi, niepełnosprawnymi lub biednymi & 2 & 3 \\
\hline Organizacje religijne lub kościelne & $1 \%$ & $3 \%$ \\
\hline Organizacje zajmujące się nauką, sztuka, muzyką, kulturą & $2 \%$ & $8 \%$ \\
\hline
\end{tabular}




\begin{tabular}{||c|c|c||}
\hline \multicolumn{1}{|c|}{1} & 2 & 3 \\
\hline Związki zawodowe & $0 \%$ & $4 \%$ \\
\hline Partie lub stowarzyszenia polityczne & $0 \%$ & $2 \%$ \\
\hline $\begin{array}{l}\text { Organizacje lokalne zajmujące się takimi sprawami jak ubóstwo, sprawy zatrudnie- } \\
\text { nia, sprawy mieszkaniowe, prawa mniejszości }\end{array}$ & $0 \%$ & $1 \%$ \\
\hline Organizacje na rzecz rozwoju krajów Trzeciego Świata lub ochrony praw człowieka & $0 \%$ & $3 \%$ \\
\hline Organizacje zajmujące się ochroną środowiska, ekologią i prawami zwierząt & $2 \%$ & $4 \%$ \\
\hline Stowarzyszenia zawodowe & $0 \%$ & $2 \%$ \\
\hline Organizacje młodzieżowe (np. harcerstwo, kluby młodzieżowe) & $8 \%$ & $8 \%$ \\
\hline Organizacje zajmujące się sportem i rekreacją & $5 \%$ & $23 \%$ \\
\hline Organizacje kobiece & $0 \%$ & $1 \%$ \\
\hline Ruchy pokojowe & $0 \%$ & $1 \%$ \\
\hline Organizacje społeczne zajmujące się problemami zdrowia & $0 \%$ & $2 \%$ \\
\hline Inne grupy działania & $0 \%$ & $4 \%$ \\
\hline Żadne & $\mathbf{7 5 \%}$ & $\mathbf{4 4 \%}$ \\
\hline
\end{tabular}

* Odsetki w kolumnach nie sumują się do 100\%, ponieważ respondenci oceniali każdą organizację oddzielnie. Odpowiedzi z kategorii „Żadne” nie były odczytywane przez ankietera i udzielane były przez respondentów spontanicznie.

Źródło: Opracowanie własne na podstawie danych EVS 2008.

\section{Podsumowanie}

Polityka w życiu codziennym większości młodych ludzi (młodzieży polskiej i europejskiej) odgrywa wręcz marginalną rolę. Nie należy się temu dziwić, szczególnie w świetle danych omawianych w niniejszym artykule. Uderzające są przede wszystkim te, które wskazuja, jak małą wagę młodzi obywatele przywiązują do polityki jako jednej z wielu spraw codziennych. Duża część z nich wykazuje słabą orientację w wydarzeniach politycznych, nie ma motywacji, aby - korzystając z mediów masowych - poszukiwać informacji politycznych. Polityka względnie rzadko bywa tematem rozmów z rodziną czy znajomymi. Czas wolny przytłaczającej większości wypełnia aktywność niezwiązana z polityką czy działalnością społeczną. Taka charakterystyka - co oczywiste - nie opisuje młodych ludzi en bloc. Wewnątrz tej kategorii daje się zaobserwować kilka stylów życia, zróżnicowanych pod względem stopnia depolityzacji. Grupa, którą to zjawisko dotyczy w najmniejszym stopniu składa się z około 5-10\% młodych obywateli. W dalszej kolejności trzeba wyróżnić grupę większą - około 40-60\%. Dla tych osób polityka pojawia się jako pewien kontekst codzienności (względnie zainteresowani polityka, sporadycznie śledzą informacje polityczne, od czasu do czasu polityka staje się tematem do rozmowy). W ich przypadku można mówić o relatywnej depolityzacji. Starają się oni kształtować swój styl życia w sposób, w którym słabo zaakcentowane jest ,uczestnictwo w życiu społeczno-politycznym”. Pozostałe osoby (jest ich około 30\%) w gruncie rzeczy w pełni - w sensie zarówno psychologicznym, jak i behawioralnym - dystansują się od polityki. 


\section{Bibliografia}

Adnanes M. (2000), Social Upheavals, Anomie and Coping Bulgarian Youth in the Nineties, w: Balkan Youth and Perception of the Other, red. P.-E. Mitev, LIK, Sofia.

Adsett M. (2003), Change in Political Era and Demographic Weight as Explanations of Youth 'Disenfranchisement' in Federal Elections in Canada 1965-2000, „Journal of Youth Studies”, t. 6, nr 3.

Almond G. A., Verba S. C. (1995), Kultura polityczna-klasyczne ujęcie, w: Władza i społeczeństwo, red. J. Szczupaczyński, Wydawnictwo Naukowe Scholar, Warszawa.

Bourdieu P. (2005), Dystynkcja. Społeczna krytyka władzy sqdzenia, Wydawnictwo Naukowe Scholar, Warszawa.

Elias N. (2011), O procesie cywilizacji. Analizy socjo- i psychogenetyczne, Wydawnictwo W.A.B., Warszawa.

Fatyga B. (2009), Szkic o konsumpcyjnym stylu życia i rzeczach jako dobrach kultury, w: Socjologia i Siciński. Style życia - Spoleczeństwo obywatelskie - Studia nad przyszłościa, red. P. Gliński, A. Kościański, Wydawnictwo IFiS PAN, Warszawa.

Giddens A. (2012), Nowoczesność i tożsamość, Wydawnictwo Naukowe PWN, Warszawa.

Howe P. (2006), Political Knowledge and Electoral Participation in the Netherlands: Comparisons with the Canadian Case, „International Political Science Review”, t. 27, nr 2.

Inglehart R. (1999), Postmodernization Erodes Respect for Authority, But Increases Support for Democracy, w: Critical Citizens, Global Support for Democratic Governance, red. P. Norris, Oxford University Press, Oxford.

Jacyno M. (2012), Style życia, w: Wspótczesne społeczeństwo polskie, red. A. Giza, M. Sikorska, Wydawnictwo Naukowe PWN, Warszawa.

Kokociński M. (2001), Negatywne elementy stylu życia młodzieży, w: Nowe style zachowań, red. M. Golka, Wydawnictwo Fundacji Humaniora, Poznań.

O’Toole T., Gale R. (2013), Political Engagement Amongst Ethnic Minority Young People: Making a Difference, Palgrave Macmillan, Basingstoke.

Palska H. (2009), Dawne i obecne badania nad stylami życia. Analiza dwu przypadków, w: Socjologia i Siciński. Style życia - Społeczeństwo obywatelskie - Studia nad przyszłościa, red. P. Gliński, A. Kościański, Wydawnictwo IFiS PAN, Warszawa.

Siciński A. (1978), Styl życia. Przemiany we wspótczesnej Polsce, Wydawnictwo Naukowe PWN, Warszawa.

Siciński A. (1988), Typy stylu życia ludności miejskiej, w: Style życia w miastach polskich (u progu kryzysu), red. A. Siciński, Zakład Narodowy im. Ossolińskich, Wrocław.

Siciński A. (2002), Styl życia, kultura, wybór, Wydawnictwo IFiS PAN, Warszawa.

Svynarenko A. (2001), National, Political and Cultural Identities of Youth: Tendencies in Post-Soviet Ukraine, w: Youth, Citizenship and Empowerment, red. H. Helve, C. Wallace, Ashgate Publishing Limited, Aldershot.

Sztompka P. (2005), Socjologia zmian społecznych, Wydawnictwo Znak, Kraków.

Tarkowska E. (2009), Perspektywa interdyscyplinarna w badaniach stylów życia, w: Socjologia i Siciński. Style życia - Społeczeństwo obywatelskie - Studia nad przyszłościa, red. P. Gliński, A. Kościański, Wydawnictwo IFiS PAN, Warszawa.

Terrén E. (2002), Post-modern Attitudes: a Challenge to Democratic Education, „European Journal of Education", t. 37, nr 2.

Tivadar B., Polona M. (red.) (2002), Flying Over or Falling Through the Cracks? Young People in the Risk Society, Ministry of Education, Science and Sport of the Republic of Slovenia, Office of the Republic of Slovenia for Youth, Ljubljana. 
Tyyskä V. (2009), Youth and Society: The Long and Winding Road, Canadian Scholars' Press, Toronto.

Veblen T. (1971), Teoria klasy próżniaczej, Wydawnictwo Naukowe PWN, Warszawa.

Vrcan S. (2002), Youth: Politics, Sub-Politics and Anti-Politics. The Case of Croatia Since the Mid-eighties, w: Flying Over or Falling Through the Cracks? Young People in the Risk Society, red. B. Tivadar, M. Polona, Ministry of Education, Science and Sport of the Republic of Slovenia, Office of the Republic of Slovenia for Youth, Ljubljana.

Weber M. (1975), Klasy, stany, partie - podział władzy w obrębie wspólnoty, w: Elementy teorii socjologicznych, red. W. Derczyński, A. Jasińska-Kania, J. Szacki, Wydawnictwo Naukowe PWN, Warszawa.

Wiatr J. J. (2009), Socjologia polityki, Europejska Wyższa Szkoła Prawa i Administracji, Warszawa.

Wilk T. (2003), Edukacja, wartości i style życia reprezentowane przez współczesna młodzież w Polsce w odmiennych regionach gospodarczych, Oficyna Wydawnicza Impuls, Kraków.

Wolska-Zogata I. (2009), Bezdomni w świetle koncepcji homo eligens, w: Socjologia i Siciński. Style życia - Społeczeństwo obywatelskie - Studia nad przyszłościq, red. P. Gliński, A. Kościański, Wydawnictwo IFiS PAN, Warszawa.

\section{Depoliticization as a Part of Youth's Way of Life}

\section{Summary}

In many scientific discussions about youth attitudes in political or public sphere we don't notice results of change of youth's way of life. However, we have to spot that the new model of everyday life eliminates politics and different political problems, because they don't present themselves as attractive issues. Politics is placed very low in value hierarchy of young people. They are passive on a political arena during their free time. Politics is not so frequent a topic of conversations with family or friends. In the article the author presents data to prove his point that appreciable part of young Europeans (especially young Poles) prefers ,depoliticized” way of life.

Key words: youth, way of life, depoliticization, political culture, participation 